\title{
PENINGKATAN MUTU PENDIDIKAN MELALUI PENILAIAN PROSES BELAJAR MENGAJAR
}

\author{
Oleh: \\ Triwahyu Budiutomo \\ Universitas Cokroaminoto Yogyakarta
}

\begin{abstract}
Abstrak
Penilaian terhadap hasil pelaksanaan proses belajar-mengajar sering diabaikan, dan sangat jarang dilakukan. Mutu pendidikan hanya diukur dari keberhasilan siswa setelah mengikuti proses belajar mengajar. Tulisan ini bertujuan untuk mengkaji upaya peningkatan mutu melalui penilaian proses belajar mengajar. Mutu pendidikan tidak hanya di ukur dari produknya saja, tetapi di mulai dari dimensi input- proses dan output. Dalam hal ini, sesuai dengan dimensi penilaian proses belajar mengajar yang meliputi input-proses dan output serta perbaikan terus menerus (countinous improvement) merupakan esensi penilaian proses belajar mengajar. Dengan pendekatan analisis sistesis kedua obyek kajian tersebut dikaitkan,

Hasil kajian menunjukan bahwa proses belajar mengajar sebagai obyek penilaian sangat tepat untuk dilakukan, khususnya dalam upaya peningkatan mutu pendidikan. Upaya peningkatan mutu pendidikan dilakukan mendasarkan pada hasil penilaian proses belajar mengajar.
\end{abstract}

Kata kunci : Mutu pendidikan, Penilaian PBM, Input-proses dan output.

\section{A. Pendahuluan}

Titik berat pembangunan pendidikan pada saat ini ditekankan pada peningkatan mutu. Konsekuensinya, perlu ditingkatkan keseluruhan komponen sistem pendidikan, baik yang bersifat human resources maupun yang bersifat material resources. Di dalam aturan perundangundangan tentang sistem pendidikan nasional, komponen-komponen sistem pendidikan yang bersifat human resources dapat digolongkan menjadi tenaga pendidikan, guru dan non guru. 
Sedangkan komponen sistem pendidikan yang bersifat material resources antara lain meliputi: kurikulum dan fasilitas fisik lainnya.

Dari hasil studinya yang berkaitan dengan komponen sistem pendidikan, Ali Imron (1995) mengemukakan bahwa peningkatan kualitas komponen-komponen sistem pendidikan yang terbukti lebih berpengaruh terhadap peningkatan mutu pendidikan adalah komponen yang bersifat human resources. Hal ini dapat dipahami dari kenyataan, bahwa komponen yang bersifat material resources tidak dapat bermanfaat tanpa adanya komponen human resources yang kompeten dan kualitas memadai. Guru adalah merupakan human resouces dalam sistem pendidikan yang harus mendapat perhatian. Peningkatan kualitas kerja guru merupakan tuntutan pokok dalam upaya peningkatan kualitas pendidikan.

Kualitas kerja guru berkaitan langsung dengan kegiatan guru dalam melaksanakan proses belajar mengajarnya. Dalam hubungan ini kualitas proses belajar mengajar yang dilakukan guru sangat menentukan keberhasilan upaya peningkatan mutu pendidikan secara keseluruhan. Keberhasilan pelaksanaan proses belajar mengajar yang dilakukan guru akan sangat menentukan tinggi rendahnya kualitas pendidikan, reasoning ini diperkuat oleh pendapat Udoji (1981) yang dengan tegas mengemukakan bahwa : " the execute of policies is as important if not more important than policy-making. Policy will remain dreams or blue prins in file jackets unless they are implemented" (pelaksanaan kebijaksanaan adalah sesuatu yang penting, bahkan mungkin jauh lebih penting daripada pembuatan kebijaksanaan. Kebijaksanaan-kebijjaksanaan akan sekedar berupa impian atau rencana bagus yang tersimpan rapi dalam arsip kalau tidak diimplementasikan). Kurikulum, silabus, rencana pembelajaran tidak akan bermanfaat tanpa adanya guru yang dapat melaksanaan pedoman-pedoman tersebut dengan baik. Sehubungan dengan hal ini, maka selain hasil belajar, penilaian terhadap proses belajar mengajar merupakan hal yang penting bagi upaya peningkatan mutu pendidikan.

Permasalahannya sekarang adalah bahwa penilaian terhadap proses belajar dan mengajar sering diabaikan, setidak-tidaknya kurang mendapat perhatian dibandingkan dengan penilaian hasil belajar. Penilaian terhadap hasil pelaksanaan proses belajar dan mengajar sangat jarang dilakukan. Keberhasilan atau mutu pendidikan hanya diukur dari keberhasilan siswa setelah mengikuti proses belajar mengajar, sedangkan bagaimana keberhasilan pelaksanaan proses belajar dan mengajar sendiri tidak diperhatikan, bagaimana keberhasilan guru dalam mengajar, 
bagaimana fasilitas yang tersedia dsb. Mendasarkan pada uraian di atas, kajian tentang proses belajar-mengajar sebagai obyek penilaian menarik untuk dilakukan. Apalagi, pendidikan tidak berorientasi kepada hasil semata-mata, tetapi juga kepada proses. Oleh sebab itu, penilaian terhadap hasil dan proses belajar-mengajar harus dilaksanakan secara seimbang, dan akan lebih baik bila dilaksanakan secara simultan. Secara rinci, tulisan ini mencoba memberikan penjelasan, Bagaimanakah keterkaitan upaya peningkatan mutu pendidikan dengan proses belajar-mengajar sebagai obyek penilaian.

\section{B. Mutu Pendidikan}

Dalam Bahasa Indonesia (BI), mutu disebut juga kualitas. Kata kualitas diadopsi dari bahasa Inggris, yaitu quality dan kata ini sesungguhnya berasal dari bahasa latin, yaitu qualitas yang masuk ke dalam bahasa Inggris melalui bahasa Perancis kuno, yaitu qualite. Dalam kamuskamus lengkap (kamus komprehensif) bahasa Inggris kata itu mempunyai banyak arti. Tiga diantaranya : (1) suatu sifat atau atribut yang khas yang membuat berbeda; (2) standar tertinggi atau kebaikan; dan (3) memiliki sifat kebaikan tertinggi.

Dari ketiga arti di atas, dapat dipahami bahwa mutu berkenaan dengan sifat dari sesuatu yang baik. Sifat yang baik itu bermacam-macam, misalnya, kecantikan, keindahan, kelezatan makanan, kenyamanan, kedamaian, kesejahteraan dan kemakmuran. Karena itu, kita sering mendengar ungkapan, lukisan itu bermutu, kehidupan desa itu bermutu, dan makanan bermutu. Dalam hal ini, ungkapan bermutu berarti mempunyai sifat-sifat yang baik atau menyenangkan bagi yang merasakannya atau mungkin juga bagi umum. Sering juga dalam pengertian umum kata bermutu berarti mempunyai sifat yang baik atau terbaik. Dalam hubungan ini, mutu mempunyai tingkatan atau bergradasi, sesuatu obyek mutu dapat saja dikatakan, bermutu tinggi, sedang, atau rendah.

Mutu berkenaan dengan sifat kebaikan, maka dapat dipahami bahwa makna itu barkaitan dengan aspek nilai, yang berbeda dari suatu kebudayaan ke kebudayaan yang lainya, bahkan dari individu ke individu lainnya. Artinya. Cantik dalam kebudayaan Indonesia, misalnya tidak sama dengan cantik dalam kebudayaan Barat. Dengan demikian, yang bermutu dalam masyarakat Barat belum tentu bermutu dalam masyarakat Indonesia, dan demikian sebaliknya. Pemahaman tentang mutu juga dipengaruhi oleh tingkat kemajuan pendidikan dan ekonomi individu serta 
masyarakat. Bagi orang dan masyarakat yang belum berpendidikan, terutama di pedesaan, misalnya makanan bermutu adalah yang enak (lezat) rasanya dan dapat membuat kenyang. Tetapi bagi orang dan masyarakat yang berpendidikan, terutama diperkotaan, makanan bermutu adalah yang bergizi, sesuai dengan ukuran kesehatan.

Daulat P Tampubolon (2001), secara rinci dan tegas mengemukakan bahwa mutu adalah paduan sifat-sifat produk yang menunjukan kemampuannya dalam memenuhi kebutuhan pelanggan langsung atau tak langsung, baik kebutuhan yang dinyatakan maupun yang tersirat masa kini dan masa depan. Dalam hubungan ini kebutuhan pelanggan dapat dijadikan kriteria atau standar mutu. Apabila hasil produk diatas standar dikatakan bermutu, sebaliknya apabila dibawah standar dikatakan tidak bermutu. Mendasarkan pada uraian di atas kita dapat menelompokkan pemahaman tentang mutu pendidikan menjadi dua, yaitu pemahaman tradisional dan baru. Dalam pemahaman tradisional, pendidikan adalah proses mengubah perilaku manusia sesuai dengan tujuan yang ditentukan. Produk pendidikan adalah lulusan. Lulusan adalah orang yang telah mengikuti pendidikan dalam periode tertentu sehingga perilakunya berubah seperti diharapkan. Perubahan perilaku dalam hal ini berkenaan dengan penguasaan pengetahuan, yaitu dari belum menguasai pengetahuan menjadi menguasainya. Karena itu mutu pendidikan hanya dilihat dari produk, dalam arti jumlah lulusan dan penguasaan atas pengetahuan atau kemampuan akademik. Apabila presentase lulusan tinggi, nilai hasil pengajaran tinggi, maka pendidikan dikatakan bermutu.

Kenyataan, banyak keluhan tentang konsepsi tersebut, nilai bagus tetapi tidak dapat mengaplikasikan dilapangan pekerjaan, atau tidak dapat mengikuti pendidikan pada level diatasnya dengan baik. Sebagai jawaban dari persoalan tersebut muncul paham baru tentang mutu pendidikan. Dalam paham baru, mutu pendidikan tidak hanya di ukur dari produknya saja tetapi input-proses-output. Mutu pendidikan diidentifikasikan pada seluruh aspek secara terpadu bukan hanya hanya pada produk (lulusan). Pengutamaan sistem dan proses-proses dalam identifikasi atribut-atribut mutu adalah prinsip yang sangat penting dalam mutu pendidikan, karena jasa-jasa pendidikan yang utama berupa proses-proses pelayanan terhadap para siswa, seperti proses belajar mengajar, pembimbingan dan praktikum. 
Mengadopsi konsep Manajemen Mutu Terpadu (MMT), atribut-atribut mutu pendidikan meliputi: relevansi, efisiensi, efektivitas, akuntabilitas, kreativitas, situasi M-M, tangibility (penampilan), empati, ketanggapan, produktivitas dan kemampuan akademik.

1. Relevansi. Kesesuaian dengan kebutuhan. Apakah isi kurikulum, silabus, dan materi pelajaran, sesuai dengan kebutuhan., cita-cita, tingkat kemampuan dll.

a. Apakah kebijakan-kebijakan akademik sesuai dengan kebutuhan siswa (mahasiswa), pemerintah dan masarakat.

b. Apakah perpustakaan tersedia buku-buku yang sesuai dengan kebutuhan kurikulum.

c. Apakah keahlian guru atau dosen sesuai dengan kebutuhan bidang studi.

d. Apakah kemampuan lulusan sesuai dengan kebutuhan dunia kerja.

2. Efisiensi. Kehematan dalam menggunakan sumber daya ( dana, tenaga, waktu, dan lain-lain ) untuk lulusan dan penyajian layanan sesuai dengan kebutuhan siswa.

3. Efektivitas. Kesesuaian perencanaan dengan hasil yang dicapai, atau ketepatan sistem, metode, dan atau proses (prosedur) yang dipergunakan untuk menghasilkan jasa yang direncanakan.

4. Akuntabilitas (Kebertanggungjawaban). Dapat tidaknya kinerja dan produk lembaga pendidikan, termasuk perilaku para pengelola, dipertanggungjawabkan secara hukum, etika akademik, agama, dan nilai budaya.

5. Kreativitas. Kemampuan lembaga pendidikan untuk mengadakan inovasi, pembaharuan, atau menciptakan sesuatu yang sesuai dengan perkembangan zaman, termasuk kemampuan evaluasi diri.

6. Situasi M-M. Suasana yang menyenangkan dan memotivasi dalam lembaga pendidikan sehingga semua orang melaksanakan tugasnya dengan senang hati, tulus, dan penuh semangat.

7. Penampilan (Tangibility). Kerapian, kebersihan, keindahan dan keharmonisan fisik lembaga, terutama para pengelola yang membuat situasi pelayanan semakin menarik.

8. Empati. Kemampuan lembaga pendidikan, khususnya para pengelola, memberikan pelayanan sepenuh dan setulus hati kepada semua civitasnya 
9. Ketanggapan (Responsivenes). Kemampuan lembaga pendidikan, khususnya para pengelola dalam memperhatikan dan memberikan respons terhadap keadaan serta kebutuhan siswa dengan cepat dan tepat.

10. Produktivitas. Kemampuan lembaga pendidikan dan seluruh staf pengelola untuk menghasilkan produk yang sesuai dengan kebutuhan siswa menurut rencana yang telah ditetapkan, baik secara kuantitatif maupun kualitatif.

11. Kemampuan akademik. Penguasaan mahasiswa atas bidang studi yang diambilnya.

12.

\section{Belajar dan Mengajar}

Belajar. Banyak definisi yang diberikan tentang belajar, Menurut Gage (1984) sebagai penganut teori-teori perilaku, belajar dapat didefinisikan sebagai suatu proses di mana suatu organisma berubah perilakunya sebagai akibat pengalaman. Belajar merupakan perubahan perilaku yang dapat diamati, yang terjadi melalui terkaitnya stimulus-stimulus dan respon-respon menurut prinsip-prinsip mekanistik.

Menurut teori-teori Gestalt-field, belajar merupakan suatu proses perolehan atau perubahan insight-insight, pandangan-pandangan (outlooks), harapan-harapan, atau pola-pola berpikir. Dalam mempermasalahkan belajar bagi siswa, penganut teori ini lebih menyukai istilah-istilah orang daripada organisma, lingkungan psikologis daripada lingkungan fisik atau lingkungan biologi, dan interaksi daripada aksi atau reaksi. Mereka berpendapat bahwa konsep-konsep orang, lingkungan psikologi, dan interaksi lebih memudahkan para guru dalam memberikan proses-proses belajar. Konsep-konsep ini memungkinkan guru untuk melihat seseorang, lingkungannya, dan interaksi dengan lingkungannya, semuanya itu terjadi pada waktu yang sama, inilah artinya "field".

Selanjutnya para penganut teori ini yakin, bahwa perilaku tidak tampak atau yang tidak dapat diamati adalah mungkin untuk dipelajari dengan cara ilmiah, misalnya pikiran-pikiran. Oleh karena memusatkan diri pada menganalisa proses-proses kognitif, maka prinsip-prinsip dan kesimpulan-kesimpulan yang mereka sarankan disebut teori-teori kognitif

Pemahaman teori-teori kognitif berbeda dengan teori-teori perilaku, mereka lebih memberi perhatian pada proses-proses mental, Penganut teori ini ingin mendapatkan jawaban bagaimana 
impresi-impresi indera dicatat dan disimpan dalam otak, dan bagaimana impresi-impresi ini digunakan dalam memecahkan masalah-masalah.

Bigge (1982) mencoba merangkum kedua perbedaan antara teori perilaku dan gestalt sebagai berikut. Teori perilaku menafsirkan belajar sebagai perubahan- perubahan tentang kekuatan variabel-variabel hipotesis yang disebut hubungan-hubungan S-R (stimulus-respon), asosiasi-asosiasi, kekuatan-kekuatan kebiasaan, atau kecenderungan-kecenderungan perilaku. Sedangkan teori "Gestalt-fields " mendefinisikan belajar sebagai reorganisasi perseptual atau "cognitif fields" untuk memperoleh pemahaman.

Mendasarkan pada uraian di atas dapat ditarik kesimpulan bahwa belajar dapat diartikan sebagai perubahan perilaku yang diakibatkan oleh pengalaman, dan dianggap sebagai faktorfaktor penyebab dasar dalam belajar. Belajar merupakan suatu proses yang terjadi pada diri seseorang, dengan tahap-tahapan, mengerti, memahami, internalisasi atau menghayati kemudian mengamalkan ( berperilaku akibat obyek belajar).

Proses belajar mengajar. Proses belajar merupakan hal yang dialami oleh siswa, suatu respon terhadap segala acara pembelajaran yang diprogramkan oleh guru. Dalam proses belajar tersebut guru meningkatkan kemampuan-kemampuan kognitif, afektif dan psikomotoriknya. Sedangkan mengajar adalah kegiatan yang dilakukan guru karena tugas profesinya.. Terdapat beberapa pengertian tentang mengajar. Engkoswara (1984:1) mengemukakan tiga pengertian, yaitu:

“(1) mengajar adalah menyampaikan pengetahuan dan ilmu pengetahuan dari seorang guru pada murid-murid; (2) mengajar ialah menanamkan sikap dan nilai-nilai pengetahuan dan ketrampilan dasar dari seseorang yang telah mengetahui dan menguasainya kepada seseorang; (3) mengajar adalah membimbing seseorang atau kelompok orang supaya belajar berhasil. Ketiga definisi itu dapat ditafsirkan pula secara luas dan berbeda-beda Namun, perbedaan itu tidak menjadi persoalan, yang penting ialah bahwa mengajar mempunyai pautan dengan belajar."

Mendasarkan pada ketiga definisi tersebut di atas, dapat ditarik benang merah bahwa mengajar adalah membimbing seseorang atau sekelompok orang supaya belajar berhasil. Oleh karena itu, proses belajar mengajar dapat diartikan sebagai program dan kegiatan yang dirancang dan dilaksanakan oleh guru dalam proses mengajarnya. Program dan kegiatan yang dirancang meliputi: materi, metode mengajar, fasilitas mengajar dan kondisi lingkungan yang diharapkan. 
Proses belajar berkaitan erat dengan kegiatan mengajar yang dilakukan oleh guru. Sehingga sering disebut sebagai proses belajar mengajar.

\section{Proses Belajar - Mengajar Sebagai Obyek Penilaian}

\section{Tujuan dan Dimensi Penilaian Proses Belajar Mengajar}

Penilaian terhadap proses belajar mengajar bertujuan agak berbeda dengan tujuan penilaian hasil belajar. Menurut Nana Sudjana (1990), penilaian hasil belajar lebih ditekankan pada derajat penguasaan tujuan pengajaran (instruksional) oleh para siswa. Lebih lanjut ditegaskan bahwa tujuan penilaian proses belajar mengajar lebih ditekankan pada perbaikan dan pengoptimalan kegiatan belajar mengajar itu sendiri, terutama efisiensi-keefektifanproduktivitasnya Beberapa diantaranya adalah : (1) efisisensi dan keefektifan pencapaian tujuan instruksional: (2) keefektifan dan relevansi bahan pengajaran; (3) produktifitas kegiatan belajar mengajar; (4) kefektifan sumber dan sarana pengajaran, dan (5) kefektifan penilaian hasil dan proses belajar.

Sejalan dengan tujuan tersebut, dimensi penilaian proses belajar mengajar berkenaan dengan komponen-komponen yang membentuk proses belajar-mengajar dan keterkaitan atau hubungan di antara komponen-komponen tersebut. Komponen pengajaran sebagai dimensi penilaian prosess belajar mengajar setidak-tidaknya mencakup: (1) tujuan pengajaran atau tujuan instruksional; (2) bahan pengajaran; (3) kondisi siswa dan kegiatan belajarnya.; (4) kondisi guru dan kegiatan mengajarnya; (5) alat dan sumber belajar yang digunakan; dan (6) teknik dan cara pelaksanaan penilaian.

Aspek-aspek yang dinilai dari komponen-komponen di atas dapat dijelaskan sebagai berikut :

Komponen tujuan instruksional yang meliputi aspek-aspek ruang lingkup tujuan, abilitas yang terkandung didalamnya, rumusan tujuan, tingkat kesulitan pencapaian tujuan, kesesuaian dengan kemampuan siswa, jumlah dan waktu yang tersedia untuk mencapainya, kesesuaiannya dengan kurikulum yang berlaku, keterlaksanaannya dalam pengajaran.

Komponen bahan pengajaran yang meliputi ruang lingkupnya, kesesuaian dengan tujuan, tingkat kesulitan bahan, kemudahan memperoleh dan mempelajarinya, daya gunanya bagi siswa, keterlaksanaan sesuai dengan waktu yang tersedia, sumber-sumber untuk 
mempelajarinya, cara mempelajarinya, kesinambungan bahan, relevansi bahan dengan kebutuhan siswa, prasayarat mempelajarinya.

Komponen siswa yang meliputi kemampuan prasyarat, minat dan perhatian, motivasi, sikap, cara belajar, kesulitan belajar, fasilitas belajar yang dimiliki, hubungan sosial dengan teman sekelas, masalah belajar yang dihadapi, karakteristik dan kepribadian, kebutuhan belajar, identitas siswa dan keluarganya yang erat kaitannya dengan pendidikan di sekolah.

Komponen guru, yang meliputi penguasaan mata pelajaran, keterampilan mengajar, sikap keguruan, pengalaman mengajar, cara mengajar, cara menilai, kemampuan mengembangkan profesinya, keterampilan berkomunikasi, kepribadian, kemauan dan kemampuan memberikan bantuan dan bimbingan kepada siswa, hubungan dengan siswa dan dengan rekan sejawatnya, penampilan dirinya, keterampilan lain yang diperlukan.

Komponen alat dan sumber belajar yang meliputi jenis alat dan jumlahnya, daya guna, kemudahan pengadaannya, kelengkapannya, manfaat bagi siswa dan guru, cara menggunakannya. Dalam alat dan sumber belajar ini termasuk alat peraga, buku sumber, laboratorium, dan perlengkapan belajr lainnya.

Komponen penilaian, yang meliputi jenis alat penilaian yang digunakan, isi dan rumusan pertanyaan, pemeriksaan dan interpretasinya,sistem penilaian yang digunakan, pelaksanaan penilaian, tindak lanjut hasil penilaian, pemanfaat hasil penilaian, administrasi penilaian, tingkat kesulitan soal, validitas dan reliabilitas soal penilaian, daya pembeda, frekuansi penilaian, dan perencanaan penilaian.

Komponen-komponen di atas sasling berhubungan satu sama lain dan membentuk suatu sistem. Oleh sebab itu, penilaian setiap komponen bukan hanya keberadaannya, tetapi juga keterkaitan aspek-aspek yang ada pada setiap komponen dan keterkaitan antar komponen itu sendiri. Sebagai contoh, menilai aspek-aspek yang terdapat dalam komponen guru harus dilihat hubungannya dengan komponen siswa, bahan, dan tujuan pengajaran. Demikian pula menilai komponen penilaian tidak terpisahkan dari komponen tujuan, bahan, dan guru.

Penilaian terhadap proses belajar mengajar menjadi tugas dan tanggungjawab guru, kepala sekolah, dan para pengawas dalam upayanya meningkatkan kualitas pendidikan, pendidikan khususnya kegiatan belajar-mengajar, sekaligus dalam hubungannya dengan pembinaan guru. 


\section{Kriteria Dalam Menilai Proses Belajar-Mengajar.}

Keberhasilan proses belajar-mengajar dapat dilihat dari efiensi, keefektifan, relevansi, dan produktivitas proses belajar mengajar dalam mencapai tujuan-tujuan pengajaran . Efisiensi berkenaan dengan pengorbanan yang relatif kecil untuk memperoleh hasil yang optimal. Keefektifan berkenaan dengan jalan, upaya, teknik, strategi yang digunakan dalam mencapai tujuan secara tepat dan cepat. Relevansi berkenaan dengan kesesuaian antara apa yang dilaksanakan dengan apa yang seharusnya dilaksanakan. Produktivitas berkenaan dengan pencapaian hasil, baik secara kualitatif maupun kuantitatif.

Beberapa kriteria yang bisa digunakan dalam menilai proses belajar-mengajar antara lain adalah :

a) Konsistensi kegiatan belajar-mengajar dengan kurikulum, keberhasilan proses belajarmengajar dilihat sejauhmana kurikulum tersebut dilaksanakan secara nyata dalam bentuk dan aspek kurikulum.

b) Keterlaksanaan oleh guru, keberhasilan proses belajar-mengajar dilihat sejauhmana kegiatan dan program yang telah direncanakan dapat dilaksanakan oleh guru tanpa mengalami hambatan, dan kesulitan yang berarti.

c) Keterlaksanaan oleh siswa, keberhasilan proses belajar mengajar dilihat sejauhmana siswa melakukan kegiatan belajar sesuai dengan program yang telah ditentukanoleh guru tanpa mengalami hambatan dan kesulitan yang berarti.

d) Motivasi belajar siswa, keberhasilan proses belajar-mengajar dapat dilihat dalam motivasi belajar yang ditunjukkan oleh para siswa pada saat melaksanakan kegiatan belajar-mengajar.

e) Keaktifan para siswa dalam kegiatan proses belajar-mengajar, penilaian proses belajarmengajar terutama dilihat adalah sejauhmana keaktifan siswa dalam mengikuti proses belajar-mengajar.

f) Interaksi guru-siswa, interaksi guru-siswa berkenaan dengan komunikasi atau hubungan timbal-balik atau hubungan dua arah antara siswa dengan guru atau antara siswa dengan siswa dalam melakukan kegiatan belajar-mengajar.

g) Keprofesionalitasan guru, profesionalitas guru berkaitan dengan kemampuan dan keahlian guru yang profesional. 
h) Kualitas hasil belajar yang dicapai oleh siswa, keberhasilan proses belajar mengajar dapat dilihat dari hasil belajar yang capai siswa.

Dari kriteria-kriteria tersebut dapat dilihat bagian-bagian mana yang telah dicapai dan bagian-bagian mana yang belum dicapai untuk kemudian dilakukan tindakan dan upaya memperbaiki.

\section{E. Peningkatan Mutu Melalui Penilaian Proses Belajar Mengajar}

Salah satu hasil yang diharapkan dari pelaksanaan penilaian terhadap proses belajarmengajar adalah mendapatkan informasi tentang bagian-bagian mana yang telah dicapai dan bagian-bagian mana yang belum dicapai dari kegiatan belajar mengajar, untuk kemudian dilakukan tindakan dan upaya perbaikan dari kegiatan belajar tersebut. Adanya penilaian terhadap proses belajar-mengajar memberikan landasan akan adanya kegiatan berbaikan terus menerus, hal ini sesuai dengan indikator mutu ( perbaikan terus menerus atau continous improvement).

Tujuan penilaian proses belajar-mengajar pada hakikatnya adalah untuk mengetahui kegiatan belajar-mengajar, terutama efisiensi, keefektifan, dan produktivitas dalam mencapai tujuan pengajaran. Dimensi penilaian proses belajar-mengajar yang berkenaan dengan komponen-komponen proses belajar-mengajar seperti tujuan pengajaran, bahan pengajar, metode dan alat, kegiatan belajar siswa, kegiatan mengajar guru, dan penilaian sesuai dengan indikator mutu pendidikan, yang meliputi :relevansi, efisiensi, efektivitas, akuntabilitas, kreativitas, situasi M-M, tangibility(penampilan), empati, ketanggapan, produktivitas dan kemampuan akademik.

Pencapaian tujuan pengajaran menggambarkan aktivitas-aktivitas yanag diselesaikan untuk mencapai sasaran belajar. Sedangkan sasaran belajar menggambarkan keadaan ideal yang ingin dicapai, terdefinisi dengan jelas serta berkaitan secara langsung dengan misi dan visi pendidikan.

Bahan pengajaran, metode dan alat, kegiatan belajar siswa dan kegiatan mengajar, keberhasilannya berkaitan erat dengan sistem organisasinya, bagaimana pengelolaan kelas dan sebagainya. Pemberdayaan terhadap guru harus dilakukan secara terus menerus, dalam arti agar supaya dapat melaksanakan tugasnya dalam mengikuti kebutuhan dan perkembangan seorang 
guru harus selalu belajar, mengembangkan pengetahuan maupun meningkatkankan ketrampilan mengajar ( teaching skill).

Oleh karena itu, hasil penilaian proses belajar-mengajar yang berupa data konsistensi kegiatan belajar-mengajar dengan kurikulum, keterlaksanaannya oleh guru, siswa, motivasi belajar siswa, keaktifan para siswa dalam kegiatan belajar mengajar, interaksi guru-siswa, kemampuan dan ketrampilan guru mengajar dan kualitas hasil belajar yang dicapai siswa dapat dipergunakan untuk menentukan kualitas belajar (mikro), maupun makro yaitu mutu pendidikan.

\section{F. Penutup}

Upaya peningkatan mutu pendidikan dapat melalui pelaksanaan penilaian terhadap proses belajar mengajar. Artinya terdapat keterkaitan yang erat antara penilaian proses belajarmengajar dengan upaya peningkatan mutu pendidikan. Mutu pendidikan pada umumnya hannya dilihat melalui tinggi rendahnya hasil belajar yang dicapai siswa.

Hasil belajar siswa dapat diprediksi dari proses belajar dan mengajar yang dilakukan guru. Dalam hubungan ini, keberhasilan pengajaran tidak hanya dilihat dari hasil belajar yang dicapai oleh siswa, tetapi juga dari segi prosesnya. Hasil belajar pada dasarnya merupakan akibat dari suatu proses belajar. Ini berarti bahwa optimalnya hasil belajar siswa tergantung pula pada proses belajar siswa dan proses mengajar guru. Oleh sebab itu, dalam upaya meningkatkan mutu pendidikan perlu dilakukan penilaian terhadap proses belajar-mengajar.

Dimensi penilaian proses belajar-mengajar dapat merupakan indikator yang menunjukkan bagian-bagian mana dari kegiatan belajar telah dicapai, dan bagian-bagian mana yang belum dicapai, untuk kemudian dilakukan tindakan upaya perbaikannya. Artinya, peningkatan kualitas (mutu) merupakan tujuan penilaian proses belajar-mengajar.

Peningkatan mutu pendidikan dilakukan melalui kegiatan belajar-mengajar yang konsisten dengan kurikulum, pelaksanaan program kegiatan siswa maupun guru, upaya peningkatan motivasi dan peningkatan keaktifan belajar siswa, membangun interaksi guru-siswa yang kondusif, peningkatan dan pengembangan kemampuan dan keterampilan guru mengajar dan peningkatan kualitas hasil belajar siswa. 


\section{Daftar Pustaka}

Bigge, M.L. , 1982, Learning theories for teachers, Fourth edition, New York : Harpen and Row

Daulat P. Tampubolon, 2001, Perguruan tinggi bermutu, Jakarta: PT. Gramedia Pustaka Utama

Dimyati dan Mudjiono, 1999, Belajar dan pembelajaran, Jakarta: Depdibud.

Engkoswara, 1984, Dasar-dasar metodologi pengajaran, Jakarta : Bina Aksara

Gege, N. L., and Berliner, D.C., 1984, Educational psychology, third edition, Boston : Houghton Miffin

Gagne, R.M, , 1985, The Cognitive psychology of school Learning , Boston : Litle Brown

Nana Sudjana, 1990, Penilaian hasil proses belajar mengajar, Bandung : PT Remaja Rosdakarya.

Popham, W.Y. 1973, Criterion referenced measurement, Cliffs, N.J., Educational Technology Publications.

Stufflebeam, D.L., 1972, Educational evaluation and decision making, Ithaca Peacock Publishers, Inc.

Vincent Gaspersz, 1997, Manajemen bisnis total, Jakarta: Indonesia Emas dan Gramedia Pustaka Utama.

, (1983/1984), Materi Dasar Pendidikan Program Akta Mengajar V Buku IIIA Psikologi Pendidikan, Jakarta., Depdikbud Ditjen Dikti 1983/1984

(1983/1984),Materi Dasar Pendidikan Program Akta mengajar V Buku Diagnostik Kesulitan Belajar, Jakarta : Depdikbud Ditjen Dikti 1983/1984

(2003), Undang-undang Republik Indonesia Nomor 20 Tahun 2003 Tentang Sistem Pendidikan Nasional, Jakarta, Departemen Pendidikan Nasional Republik Indonesia 